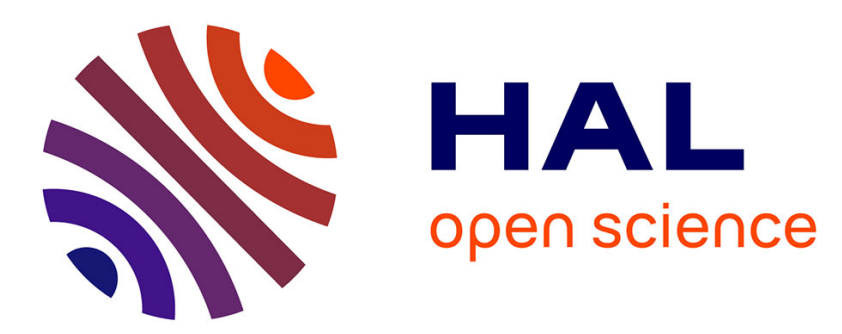

\title{
Removal of phenolic compounds from aqueous solution by activated carbon cloths
}

\author{
Catherine Faur Brasquet, E. Subrenat, P Le Cloirec
}

\section{To cite this version:}

Catherine Faur Brasquet, E. Subrenat, P Le Cloirec. Removal of phenolic compounds from aqueous solution by activated carbon cloths. Water Science and Technology, 1999, 39 (10-11), pp.201-205. 10.1016/S0273-1223(99)00277-2 . hal-03394353

\section{HAL Id: hal-03394353 \\ https://hal.science/hal-03394353}

Submitted on 22 Oct 2021

HAL is a multi-disciplinary open access archive for the deposit and dissemination of scientific research documents, whether they are published or not. The documents may come from teaching and research institutions in France or abroad, or from public or private research centers.
L'archive ouverte pluridisciplinaire HAL, est destinée au dépôt et à la diffusion de documents scientifiques de niveau recherche, publiés ou non, émanant des établissements d'enseignement et de recherche français ou étrangers, des laboratoires publics ou privés. 


\title{
REMOVAL OF PHENOLIC COMPOUNDS FROM AQUEOUS SOLUTION BY ACTIVATED CARBON CLOTHS
}

\author{
C. Brasquet*, E. Subrenat** and P. Le Cloirec* \\ * Ecole des Mines de Nantes, DSEE, 4 rue A. Kastler, BP 20277, 44307 Nantes \\ Cedex 03, France \\ ** Actitex, 16 rue Trézel, 92300 Levallois Cedex, France
}

\begin{abstract}
Granular activated carbon (GAC) is easily used in water or wastewater treatment in order to remove organic micropollutants. Recently, a new presentation of activated carbon has been developed: fibrous activated carbon in the form of cloth or felt. This work investigates the adsorption onto activated carbon cloths (ACC) of various phenolic compounds from aqueous solution. Experiments were carried out in batch reactors with two ACCs (called CS 1501 and RS 1301) and their performances were compared with those of GAC. Initial adsorption kinetic coefficients were higher with fibers than with granules due to the direct connection of micropores to the external surface of fibers. Adsorption isotherms were also performed and modelized by Langmuir and Freundlich equations. Adsorption capacities were similar or higher with ACCs than with GAC. The behaviour of the ACC CS 1501 was also studied in a dynamic reactor. The breakthrough curves allowed the determination of high maximum adsorption capacities, $117 \mathrm{mg} \cdot \mathrm{g}^{-1}$ for phenol. Pressure drops in ACC beds were measured and the influence of various parameters was shown: the activation step, the number of fabric layers, the space between two layers. O 1999 IAWQ Published by Elsevier Science Ltd. All rights reserved
\end{abstract}

\section{KEYWORDS}

Activated carbon cloth; adsorption; batch reactor; dynamic reactor; phenolic compounds; pressure drops.

\section{INTRODUCTION}

Organic matter and micropollutants are readily removed in water treatment using granular or powdered activated carbon. Activated carbon fibers (ACF) in the form of cloth or felt have received an increasing attention in recent years as an adsorbent for purifying water (Economy et al., 1996 ; Brasquet and Le Cloirec, 1997). They are produced from a natural or synthetic precursor by carbonisation and activation at $800 / 1000^{\circ} \mathrm{C}$ by $\mathrm{CO}_{2}$ or steam (Suzuki, 1991). ACFs have high specific surface areas $\left(800-2000 \mathrm{~m}^{2} \mathrm{~g}^{-1}\right.$ ) and microporosity, with the micropores directly connected to the fiber's external surface (Ryu, 1990) having a diameter ranging from 5 to 21 \& (Sakoda et al., 1987).

The main objective of the present study was to assess the performance of ACCs in water treatments for phenolic compounds removal. Adsorption is carried out in a batch reactor in order to compare the adsorption rates and capacities of activated carbon cloths and granules. In the second part, the adsorption takes place onto one specific ACC in a dynamic reactor. A hydrodynamic study is also carried out. 


\section{METHODS}

\section{Activated carbon characteristics}

The characteristics of the different activated carbons are given in Table 1. Specific surface areas and volumes were determined by the Brunauer Emmet and Teller (BET) method by nitrogen adsorption at $77 \mathrm{~K}$. Table 1 shows that ACCs have high BET surface areas, bigger than that of the GAC. They are mainly microporous (>96\% of microporous volume for the CS 1501), even if the RS 1301 has only $68.1 \%$ of micropores. This result was supported by Scanning Electron Micrographs, which have been reported previously (Le Cloirec et al., 1997).

Table 1. Main characteristics of the activated carbon materials (Actitex and Pica co., Levallois, France)

\begin{tabular}{lccc}
\hline Sample identifier & CS 1501 & RS 1301 & NC 60 \\
\hline Presentation & Cloth & cloth & Granules \\
Producer & Actitex & Actitex & Pica \\
BET surface area $\left(\mathrm{m}^{2} \mathrm{~g}^{-1}\right)$ & $>1500$ & $>1300$ & $>1200$ \\
Micropore surface area $(\%)$ & 87.5 & 77.2 & 76.0 \\
Micropore volume $(\%)$ & 96.3 & 68.1 & 94.4 \\
Median pore diameter $(\AA)$ & 6.9 & 7.3 & 7.3 \\
\hline
\end{tabular}

Kinetic and equilibrium studies

The adsorption of various phenolic compounds commercially available (phenol, 4-chlorophenol, 4nitrophenol, 2-tertbutyl-4-methyl phenol) was carried out in a batch reactor. They were analyzed in the UV region with a spectrophotometer UV-2101 PC Shimadzu. Two sets of adsorption experiments were performed, both at $20 \pm 1^{\circ} \mathrm{C}$ : kinetics and isotherms. Kinetic experiments were carried out with $0.5 \mathrm{~g}$ of activated carbon in the form of cloth or granules stirred in 11 of solution containing $100 \mathrm{mg} \mathrm{l}^{-1}$ of phenolic compound. Samples were withdrawn at regular times to plot the concentration of organic as a function of time. For the isotherm experiments, various weights (from 0.025 to $0.5 \mathrm{~g}$ ) of activated carbon were stirred in $0.250 \mathrm{l}$ of a solution containing $100 \mathrm{mg} \mathrm{l}^{-1}$ of phenolic pollutant. The contact time to reach equilibrium was 12 hours for fibers and 48 hours for granules.

\section{Hydrodynamic study: adsorption and pressure drops}

The pilot unit shown in Figure 1 was used for this study. The ACC was held in a disk of internal diameter 40 $\mathrm{mm}$, put into a tube with the same internal diameter. Several fabric layers could be held in one disk, and the distance between two disks could range from 0 to $10 \mathrm{~cm}$.

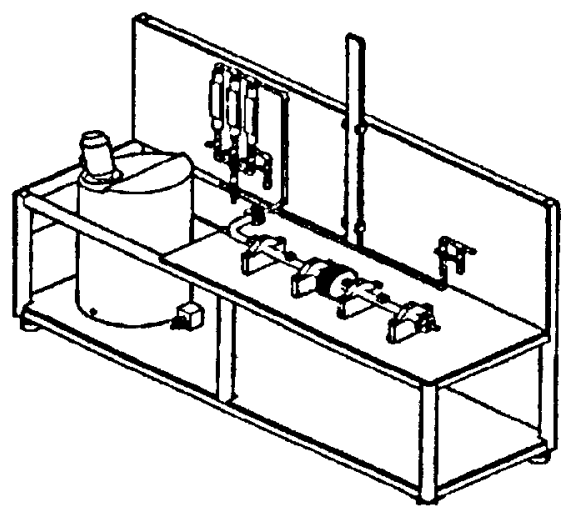

Figure 1. Pilot unit. 
The adsorption study was carried out using an aqueous solution containing phenol with a concentration of 10 $\mathrm{mg}^{-1}$, which was delivered at the tube inlet with a flow velocity of $0.6 \mathrm{~m} \mathrm{~h}^{-1}$. Six CS 1501 layers were held into the disk. Samples were withdrawn at regular times at the outlet of the ACC bed in order to plot the breakthrough curve.

The hydrodynamic study, in terms of pressure drops, was carried out with the same pilot unit. Tap water was delivered at the inlet of the tube, with a velocity ranging from 0 to $0.08 \mathrm{~m} \mathrm{~s}^{-1}$. Pressure drops at either end of the fabric bed were measured as a function of water velocity, and the influence of different parameters was studied: the activation, the bed length and the distance between several cloth layers. Pressure drops in the tube without cloth were negligible.

\section{RESULTS AND DISCUSSION}

\section{Kinetic and equilibrium studies}

For the four phenolic compounds, kinetic curves on the two ACCs and the GAC are given in Figures 2-5. The initial adsorption kinetic coefficients $\gamma$ were calculated (Le Cloirec et al., 1997); they are given in Table 2. The initial adsorption velocities are higher with fibers than with granules because of micropores which are directly connected to the external surface of fibers. Migration distances and mass transfer resistances are then reduced compared with GAC. In the case of 4-chlorophenol and 2-tertbutyl-4-methyl phenol, the adsorption velocities are higher with the RS 1301 than with the CS. 1501. This result may be due to a lower accessibility of the CS 1501 micropores to these adsorbates which have a larger molecular size, their adsorption onto RS 1301 being facilitated by the higher mesopores concentration of this ACC.
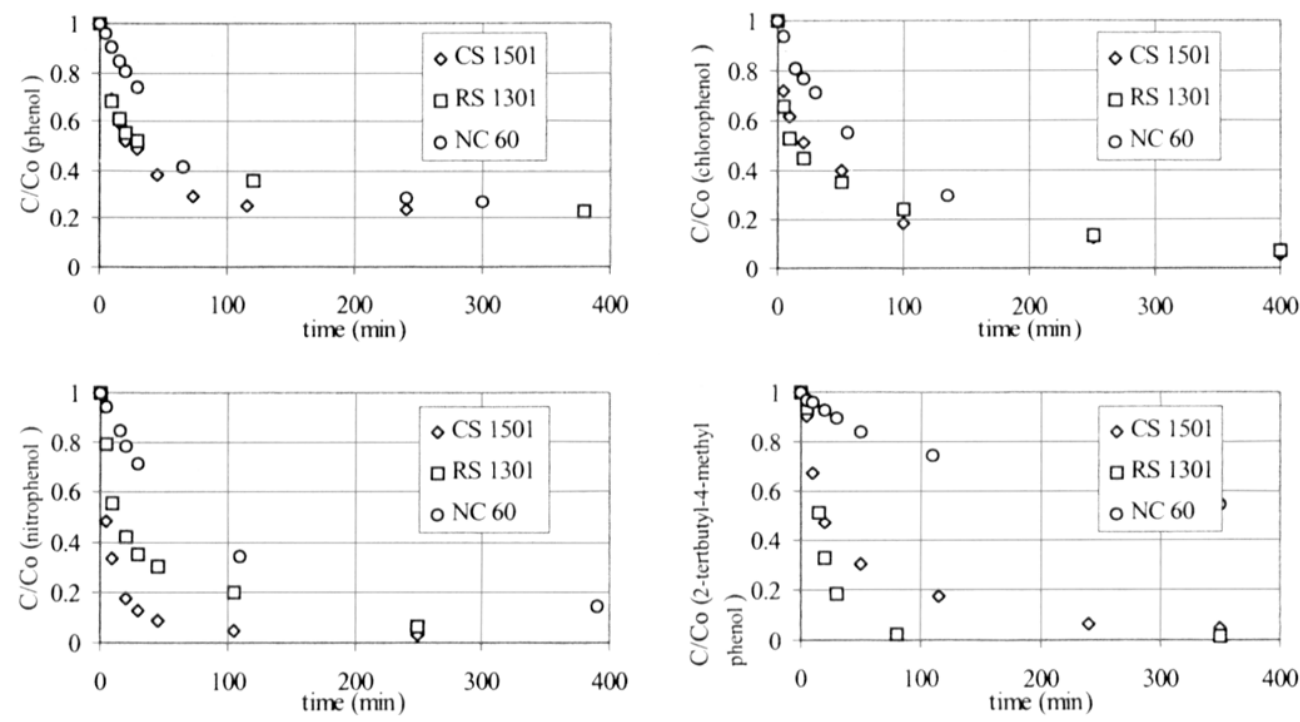

Figures 2-5. Adsorption kinetic curves of phenol, 4-chlorophenol, 4-nitrophenol and 2-tertbutyl-4-methyl phenol on two ACCs (CS 1501 and RS 1301) and one GAC (NC 60); Co $=100 \mathrm{mg} \mathrm{l}^{-1}, \mathrm{~V}=1 \mathrm{l}$.

Classical models of Freundlich and Langmuir were applied to the experimental isotherms to compute $\mathrm{K}$ $\left(m g^{1-1 / n} L^{1 / n} g^{-1}\right)$ and $1 / n$, Freundlich parameters, $q_{m}$, the maximum adsorption capacity $\left(\mathrm{mg} \mathrm{g}^{-1}\right)$ and $b$, the Langmuir equilibrium parameter $\left(\mathrm{L} \mathrm{mg}^{-1}\right)$. Values are given in Table 2 and they show that adsorption capacities are higher with ACCs than with the GAC, because of the higher BET surface area of the ACC. 
Table 2. Initial adsorption kinetic coefficients and Freundlich and Langmuir parameters

\begin{tabular}{ccccccccc}
\hline & & \multicolumn{4}{c}{ Freundlich } & \multicolumn{3}{c}{ Langmuir } \\
\hline Compound & $\mathrm{AC}$ & $\begin{array}{c}\gamma \times 10^{5} \\
\left(\mathrm{~L} \mathrm{mg}^{-1} \mathrm{~min}^{-1}\right)\end{array}$ & $\begin{array}{c}\mathrm{K} \\
\left(\mathrm{mg}^{\left.1-1 / 1 / \mathrm{L}^{1 / 1 /} \mathrm{g}^{-1}\right)}\right.\end{array}$ & $1 / \mathrm{n}$ & $\mathrm{r}$ & $\begin{array}{c}\mathrm{q}_{\mathrm{m}} \\
\left(\mathrm{mg} \mathrm{g}^{-1}\right)\end{array}$ & $\begin{array}{c}\mathrm{b} \\
\left(1 \mathrm{mg}^{-1}\right)\end{array}$ & $\mathrm{r}$ \\
\hline Phenol & CS 1501 & 4.8 & 56.0 & 0.354 & 0.96 & 208.0 & 0.193 & 0.92 \\
& RS 1301 & 4.2 & 43.9 & 0.300 & 0.99 & 118.1 & 0.520 & 0.94 \\
4-chlorophenol & NC 60 & 1.9 & 50.3 & 0.289 & 0.99 & 184.2 & 0.116 & 0.98 \\
& CS 1501 & 4.8 & 131.6 & 0.206 & 0.99 & 207.9 & 2.350 & 0.95 \\
& RS 1301 & 5.5 & 141.2 & 0.271 & 0.99 & 233.1 & 2.270 & 0.96 \\
4-nitrophenol & NC 60 & 2.3 & 122.7 & 0.220 & 0.98 & 233.1 & 1.160 & 0.96 \\
& CS 1501 & 8.2 & 187.5 & 0.110 & 0.97 & 280.9 & 1.200 & 0.98 \\
& RS 1301 & 5.7 & 196.2 & 0.153 & 0.97 & 333.3 & 0.840 & 0.94 \\
2-tertbutyl-4-methyl & NC 60 & 2.1 & 174.7 & 0.150 & 0.99 & 301.2 & 0.073 & 0.97 \\
phenol & CS 1501 & 5.2 & 301.0 & 0.117 & 0.99 & 427.4 & 0.549 & 0.94 \\
& RS 1301 & 6.7 & 207.7 & 0.167 & 0.98 & 343.6 & 1.060 & 0.95 \\
& NC 60 & 0.7 & 74.5 & 0.328 & 0.99 & 273.2 & 0.164 & 0.97 \\
\hline
\end{tabular}

\section{Hydrodynamic study}

Figures 6-8 show respectively the effect of the activation, of the cloth layers number and of the distance between two cloth layers on pressure drops. Figure 6 compares pressure drops as a function of water velocity through one layer of CS 1501 as-received (rayon fabric) and made up of activated carbon fibers. It shows that activation induces a decrease of pressure drops in the cloth. During the activation step, volatile materials are removed and fiber size decreases, as the bed porosity increases. Figure 7 shows that pressure drops per unit length are similar for one and two cloth layers. It means that head losses are additive when there is no distance between two cloth layers. However, Figure 8 shows that for a high water flow velocity, the pressure drops increase as the distance between two cloth layers increases. For highest velocities, a velocity perturbation is induced by the space between the two layers which have an influence on the pressure drops.

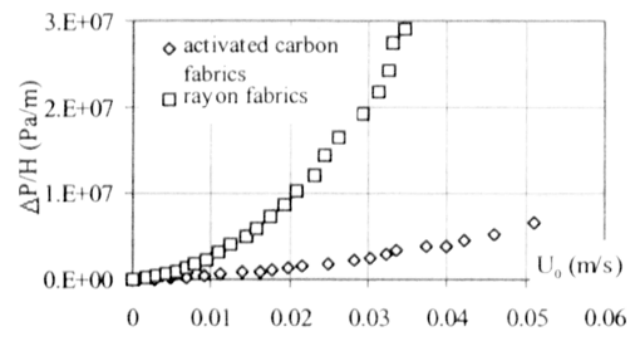

Figure 6. Effect of the activation on $\Delta \mathrm{P} / \mathrm{H}$.

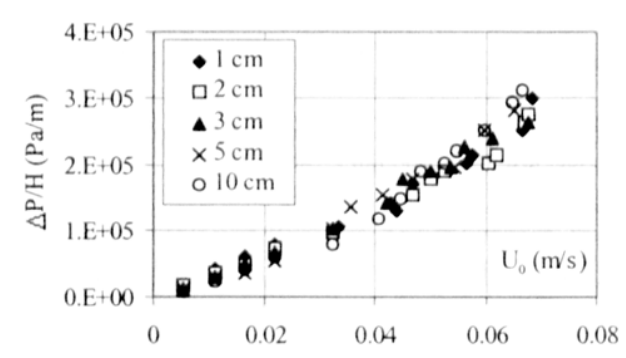

Figure 8. Effect of the distance between 2 cloth layers on $\Delta P$.

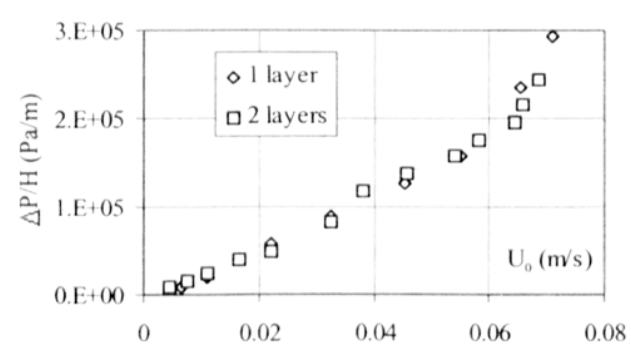

Figure 7. Effect of cloth layers number on $\Delta \mathrm{P} / \mathrm{H}$.

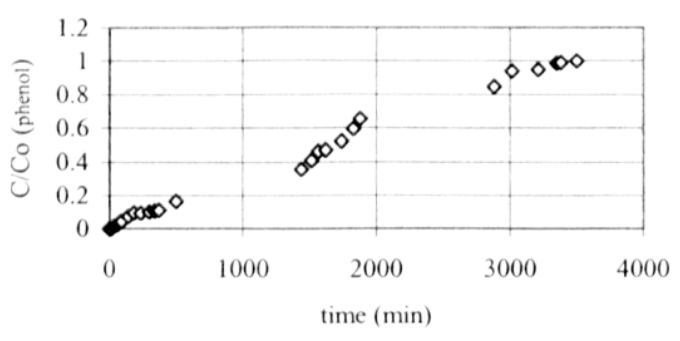

Figure 9. Breakthrough curve of phenol on CS 1501; $C_{0}=10 \mathrm{mg} \mathrm{L}^{-1}, 6$ cloth layers, Uo $=0.6 \mathrm{~m} \mathrm{~h}^{-1}$.

The adsorption of phenol was studied with 6 layers of the ACC CS 1501. The breakthrough curve is given in Figure 9. Its shape is steep, suggesting a small mass transfer resistance, smaller than for a bed of granules 
(Ryu, 1990; Suzuki, 1991). The maximum adsorption capacity was $108 \mathrm{mg} \mathrm{g}^{-1}$, a high value compatible with previous data in the literature (Petokovska and Mitrovic, 1989).

\section{CONCLUSION}

This study has shown the performance of activated carbon cloth to remove phenolic compounds from aqueous solution in batch and dynamic reactors. The good kinetic and hydrodynamic performance of fibers enables us to imagine and propose new and smaller reactors.

\section{REFERENCES}

Brasquet, C. and Le Cloirec, P. (1997). Adsorption onto ACFs, applications to water and air treatments. Carbon, 35(9), 1307-1313.

Economy, J., Daley, M. A. and Mangun, C. (1996). Activated carbon fibers: past, present and future. Am. Chem. Soc., Div. Fuel Chem., 41(1), 321-325.

Le Cloirec, P., Brasquet, C. and Subrenat, E. (1997). Adsorption onto fibrous activated carbon : applications to water treatments. Energy Fuels, 11(2), 331-336.

Petekovska, M. and Mitrovic, M. (1989). Dynamic and cyclic adsorption from liquid phase on fibrous activated carbon. Chem. Biochem. Eng. Q., 3(4), 153-159.

Ryu, S. K. (1990). Porosity of activated carbon fibers. High Temp. High Press., 22, 345-354.

Sakoda, A., Kawazoe, K. and Suzuki, M. (1987). Adsorption of tri- and tetrachloroethylene from aqueous solution on activated carbon fibers. Wat. Res., 21(6), 717-722.

Suzuki, M. (1991). Application of fiber adsorbents in water treatment. Wat. Sci. Tech., 23(7-9), 1649-1658. 